\title{
LIQUID CHROMATOGRAPHY-MASS SPECTROMETRY METHODS FOR THE DETERMINATION OF ANDARINE AND OSTARINE IN RAT SERUM AFTER PROTEIN PRECIPITATION
}

\author{
AMALIA MIKLOS ${ }^{1}$, AMELIA TERO-VESCAN ${ }^{1 *}$, LENÁRD FARCZÁDI $^{2,3}$, SILVIA IMRE $^{1,2}$, \\ CAMIL-EUGEN VARI ${ }^{1}$, DANIELA-LUCIA MUNTEAN ${ }^{1}$ \\ ${ }^{I}$ Faculty of Pharmacy, University of Medicine, Pharmacy, Sciences and Technology, 38 Gheorghe Marinescu Street, 540139 , \\ Târgu Mureș, Romania \\ ${ }^{2}$ Center for Advanced Medical and Pharmaceutical Research (CCAMF), University of Medicine, Pharmacy, Sciences and \\ Technology, 38 Gheorghe Marinescu Street, 540139, Târgu Mureş, Romania \\ ${ }^{3}$ Faculty of Pharmacy, "Iuliu Hațieganu” University of Medicine and Pharmacy, 8 Victor Babeş Street, 400012, Cluj- \\ Napoca, Romania
}

*corresponding author: amelia.tero-vescan@umfst.ro

Manuscript received: December 2018

\begin{abstract}
Quantitative determination of andarine and ostarine in rat serum was achieved using two selective liquid chromatographymass spectrometry methods (LC-MS). After extracting the analytes and internal standards (ostarine and andarine) from the serum samples through a high throughput extraction method (protein precipitation), the samples were analysed by reverse phase liquid chromatography using as mobile phase a mixture of methanol and $10 \mathrm{mM}$ ammonium formate solution (75:25, $\mathrm{v} / \mathrm{v})$. The analytes were detected following specific transitions in MS/MS mode of the QTOF mass spectrometer, after preionization by a negative electrospray ionization source (ESI-). Both methods were validated for a concentration range between $50-10000 \mathrm{ng} / \mathrm{mL}$ according to the current official guidelines with regards to carry-over, selectivity, linearity, within- and between-run accuracy, precision and can be applied to accurately measure andarine and ostarine levels in rat serum samples in order to design a pharmacokinetic study or for doping control purposes.
\end{abstract}

\section{Rezumat}

Determinarea cantitativă a andarinei și ostarinei în serul de şobolan a fost realizată utilizând două metode selective de cromatografie de lichide cuplată cu spectrometrie de masă (LC-MS). După extracția analiţilor și a standardelor interne (ostarina şi andarina) din probele de ser printr-o metodă ,high throughput” de extracție (precipitare de proteine), probele au fost analizate prin cromatografie de lichide în fază inversă, utilizând ca fază mobilă un amestec de metanol şi o soluţie de formiat de amoniu $10 \mathrm{mM}(75: 25, \mathrm{v} / \mathrm{v})$. Analiții au fost detectați urmărind tranziții specifice în modul MS/MS al spectrometrului de masă QTOF, după ionizarea prealabilă prin sursa de ionizare de tip electrospray negativ (ESI-). Metodele au fost validate pe domeniul de concentraţie $50-10000 \mathrm{ng} / \mathrm{mL}$ în conformitate cu reglementările actuale în ceea ce privește carry-over-ul, selectivitatea, liniaritatea, precizia în aceeaşi serie şi între serii diferite și pot fi aplicate pentru cuantificarea nivelurilor serice de andarină și ostarină din probe de șobolan, pentru realizarea unui studiu farmacocinetic sau în controlul dopajului.

Keywords: andarine, ostarine, LC-MS, rat, protein precipitation

\section{Introduction}

Andarine and ostarine are two arylpropionamidederived substances from the category of Selective Androgen Receptor Modulators (SARMs) with anabolic effects, acting as agonists of the androgen receptors located in bone and muscle tissue $[3,6,8]$. Actually, these compounds are not available as approved pharmaceutical substances, being introduced in the Prohibited List of WADA (World Anti-Doping Agency) since 2008 after several reports regarding their use as doping agents $[2,12,21]$.

The scientific literature offers a variety of studies regarding the pharmaco-toxicological profiles of other different doping agents, considering that nowadays the interest for these substances is increasing amongst athletes and teenagers [16-18]. Moreover, the development of fast, sensitive, specific and robust methods in different biological matrices (mainly in urine, but also in hair) is researched in order to control the prohibited consumption of these compounds, including SARMs $[4,11,19]$.

Regarding the therapeutic effects of novel SARM compounds (YK11, S42 and GSK2881078) in certain pathologies like osteoporosis, hypogonadism, cachexia are still researched, even if the first representatives of this class do not have yet a clearly defined toxicological profile in long-term administration [5, $10,13-15,21]$. 
Taking into account that the state-of-the-art regarding the SARMs` subject includes several doping control methods in urine, our purpose was to develop and validate a fast and cost-effective LC-MS method for the quantitative analysis of andarine and ostarine (parent compounds) in rat serum samples through protein precipitation, using as internal standards ostarine for the andarine method and andarine for the ostarine method. These methods are part of a pharmacokinetic study for toxicological research purposes on animal doping model in rats treated with andarine and ostarine, respectively.

\section{Materials and Methods}

Chemicals, reagents

Andarine reference standard was purchased from SigmaAldrich (Saint Louis, USA) and ostarine reference standard from AbMole BioScience (Brussels, Belgium). Methanol, acetonitrile and ammonium formate were HPLC grade (Merck KgaA, Darmstadt, Germany). Ultrapure water was produced by a Merck Millipore Direct Q3 (Molsheim, France) water system.

Preparation of solutions

Stock solution of andarine $(100 \mu \mathrm{g} / \mathrm{mL})$ was daily prepared by dissolving $2 \mathrm{mg}$ of andarine reference standard substance (weighed on a Partner Corporation analytical balance) in $20 \mathrm{~mL}$ methanol, then $1 \mathrm{~mL}$ of this solution was diluted with methanol to $10 \mathrm{~mL}$ (final concentration $10 \mu \mathrm{g} / \mathrm{mL}$ ).

Stock solution of ostarine $(100 \mu \mathrm{g} / \mathrm{mL})$ was prepared by dissolving $2 \mathrm{mg}$ of ostarine reference standard substance in $20 \mathrm{~mL}$ methanol, then $1 \mathrm{~mL}$ of this solution was diluted with methanol to $10 \mathrm{~mL}$ (final concentration $10 \mu \mathrm{g} / \mathrm{mL}$ ).

The internal standard solutions of ostarine and andarine, respectively, were prepared in the same way as the stock solutions, having the final concentrations 10 $\mu \mathrm{g} / \mathrm{mL}$.

Seven calibration working solutions of andarine, respectively, ostarine, from $50 \mathrm{ng} / \mathrm{mL}$ to $10000 \mathrm{ng} / \mathrm{mL}$ $(50,100,500,1000,2000,5000,10000 \mathrm{ng} / \mathrm{mL})$ were prepared by diluting specific volumes of stock solutions with $10 \mathrm{mM}$ ammonium formate solution in ultrapure water.

For the preparation of blank, standard calibration and control samples serum obtained from untreated rats was used.

Standard calibration solutions and quality control samples were freshly prepared on the day of analysis. $100 \mu \mathrm{L}$ of the appropriate working solution, $100 \mu \mathrm{L}$ blank serum, and $20 \mu \mathrm{L}$ internal standard solution $(10 \mu \mathrm{g} / \mathrm{mL})$ were added in an Eppendorf tube to which $600 \mu \mathrm{L}$ of acetonitrile was added. The mixture was vortexed for 2 minutes at $2000 \mathrm{rpm}$ and centrifuged at $12000 \mathrm{rpm}$ for 10 minutes. The supernatant was transferred to a HPLC vial in order to be injected into the LC-MS/MS system.

Accuracy and precision of the method was verified using quality control samples (QCs) at three different concentrations (QCA, QCB, QCC). For andarine method, the QCs concentrations were 150, 3000, $7500 \mathrm{ng} / \mathrm{mL}$ and for ostarine method the QCs concentrations were $150,4000,7500 \mathrm{ng} / \mathrm{mL}$. The preparation of the working solutions was the same for both andarine and ostarine methods respectively, as for the determination of andarine, ostarine was used as internal standard and vice versa.

Analytical methods

The HPLC system was a Flexar FX-10 (Perkin Elmer, Waltham, USA) consisting of a binary pump, a solvent degasser, an autosampler with controlled temperature and a column thermostat. The mass spectrometry system used was an QTOF 4600 series (ABSciex). Other equipment: 5430R centrifuge (Eppendorf), ZX4 Advanced IR vortex mixer (Velp), XA52.3Y balance (Radwag), Direct 3Q UV water purification system (MerckMillipore).

Chromatographic separation for both methods was performed on a Kinetex XB-C18, $3.0 \times 100 \mathrm{~mm}$, $2.6 \mu \mathrm{m}$ column thermostated at $25^{\circ} \mathrm{C}$ and the mobile phase consisted of a mixture of water containing 10 $\mathrm{mM}$ ammonium formate (25\%) and methanol (75\%) in isocratic elution. The pump delivered the mobile phase at $0.5 \mathrm{~mL} / \mathrm{min}$, the injection volume was $2 \mu \mathrm{L}$ and the time of analysis was $2 \mathrm{~min}$ per sample analysed. The detection of the analytes was performed in MS/MS (Product ion) mode using negative electrospray ionization (ESI-). The mass spectrometer ionization source parameters were: spray voltage $1800 \mathrm{~V}$, vaporizer temperature $450^{\circ} \mathrm{C}$, Ion Gas Source 1: 35 , Ion Gas Source 2: 23, Curtain Gas: 10.

For the detection, the sum of the monitored fragment ions with $\mathrm{m} / z$ 289.05, 261.05, 205.05, 150.05 and 107.05 from parent ion $\mathrm{m} / \mathrm{z} 440.10$ for andarine, using a collision energy of $32 \mathrm{~V}$ (Figure 1) and the sum of the monitored fragment ions $m / z 269.05,185.05,118.05$ from parent ion $388.05 \mathrm{~m} / \mathrm{z}$ for the detection of ostarine using a collision energy of $23 \mathrm{~V}$ (Figure 2), were used. 


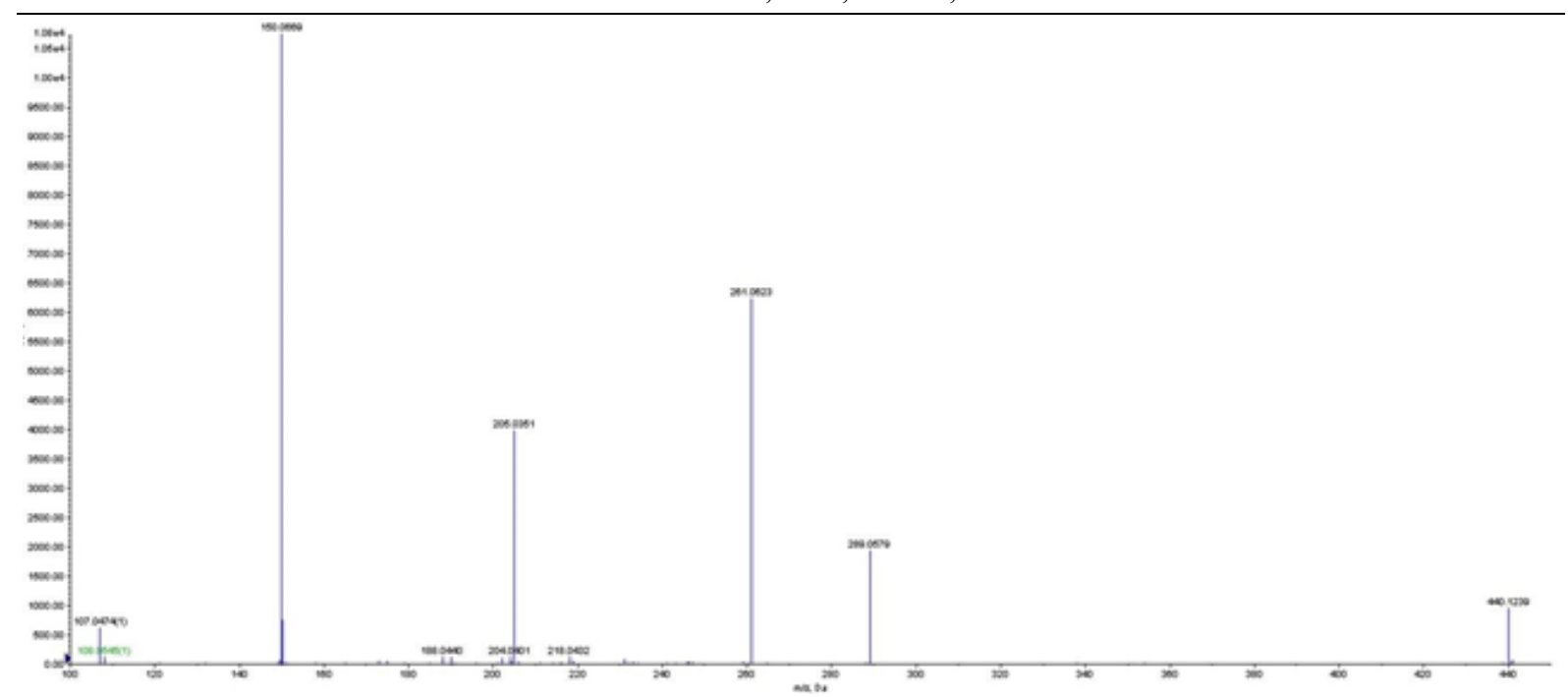

Figure 1.

Mass spectra of andarine fragmentation (Product ion scan)

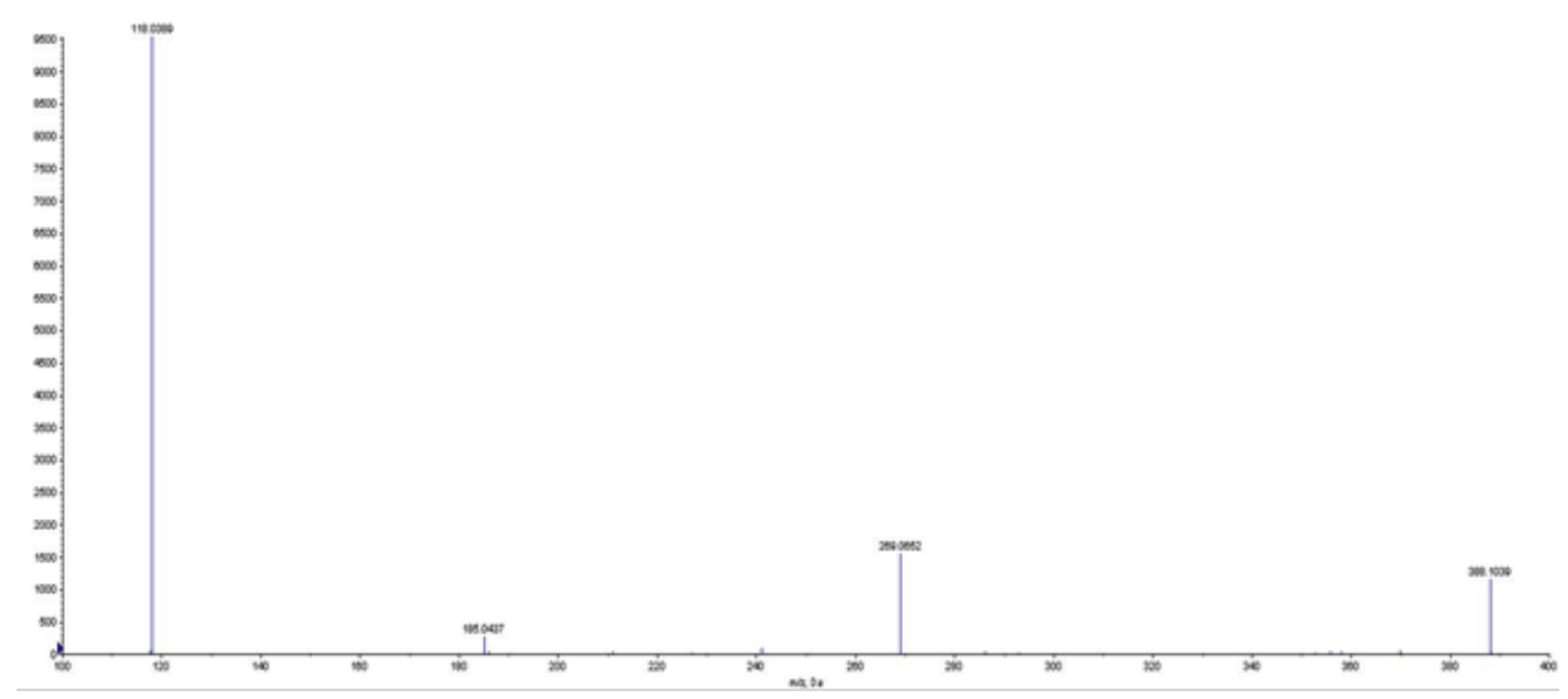

Figure 2.

Mass spectra of ostarine fragmentation (Product ion scan)

\section{Samples preparation}

Rat serum samples were freshly processed on the day of analysis as follows: in an Eppendorf tube $100 \mu \mathrm{L}$ of $10 \mathrm{mM}$ ammonium formate, $100 \mu \mathrm{L}$ serum sample, $20 \mu \mathrm{L}$ internal standard solution of $10 \mu \mathrm{g} / \mathrm{mL}$ and $600 \mu \mathrm{L}$ of acetonitrile were added, then the mixture was vortexed for 2 minutes at $2000 \mathrm{rpm}$ and centrifuged at $12000 \mathrm{rpm}$ for 10 minutes. The supernatant was transferred to a HPLC vial and a volume of $2 \mu \mathrm{L}$ was injected into the LC-MS/MS system.

All sampling and analysis were performed under the approval of The Ethical Committee for Scientific Research of The University of Medicine, Pharmacy, Sciences and Technology from Târgu Mureş, Romania (Ethical Committee approval no. 144/16.07.2019).

Validation

Both methods were validated according to the current European guideline of bioanalytical method validation regarding the selectivity, linearity, accuracy, precision, analytes stability [1].

Selectivity was tested using six different serum blanks in order to test the lack of interference from endogenous compounds at the retention times of the analytes. The carry-over was also tested, using blank sample injections made immediately after the injection of a high concentration quality control sample (QCC). The concentration of both analytes was determined using the internal standard method and the calibration was performed using singlicate calibration standards (seven standards at different levels of concentration between $50-10000 \mathrm{ng} / \mathrm{mL}$ ) in five different analytical runs analysed on three different days. The calibration curves were fitted with linear regression $y=a x+b$, weighting $1 / \mathrm{y}^{2}$, where $\mathrm{y}$ - area ratio and $\mathrm{x}$ - concentration. The within- and between-run precision (RSD\%) and accuracy (Bias\%) were determined by analysing five individual samples in the same analytical run and five 
samples, each in a separate analytical run, respectively, at four different concentration levels: LLOQ, QCA, QCB, QCC.

Another step of the method validation was the testing of analytes stability in different conditions in order to verify that analytes consistency is in accordance with regulatory provisions regarding the limits of variability in each process during a bioanalytical protocol: freeze-thaw stability (FTS), short term room temperature stability (STS) and post-preparative stability (PPS). For the stability studies, QCA and QCC levels were tested. Stock solutions were freshly prepared in each day of analysis.

FTS was tested by using five aliquots at the QCA and QCC concentration levels which were frozen and thawed two times in two consecutive days, after seven days of storage at $-20^{\circ} \mathrm{C}$. After the second freezethaw cycle, the samples were analysed against the calibration curve of the day.

Accordingly with the current European guideline of bioanalytical method validation [1], the temperature of $-20^{\circ} \mathrm{C}$ was selected as suitable for testing the stability at cooler temperatures. No long term stability was performed because the time between collection, storage and analysis was designed so that no more than 7 days of storage at $-20^{\circ} \mathrm{C}$ would be expected, and this type of stability was tested.

Four quality control samples at QCA and QCC levels were prepared mixing $100 \mu \mathrm{L}$ from the corresponding QC working solution with $100 \mu \mathrm{L}$ blank serum and leaving the mixture at room temperature for $6 \mathrm{~h}$ before testing STS.
For the PPS, five aliquots at QCA and QCC levels were tested, being stored after preparation for $18 \mathrm{~h}$ in the HPLC's autosampler at $20^{\circ} \mathrm{C}$.

All the stability serum samples were measured against a freshly prepared calibration curve and the concentrations obtained were compared to the nominal concentrations. The stability would be proven if the differences between the mean concentrations of the analysed samples in various conditions and the nominal concentrations were within the $\pm 15 \%$ acceptance limit.

The ability to dilute samples with concentrations above the upper limit of quantification (ULOQ $10000 \mathrm{ng} / \mathrm{mL}$ ) was also tested, by diluting a solution of $85000 \mathrm{ng} / \mathrm{mL}$ for andarine and $80000 \mathrm{ng} / \mathrm{mL}$ for ostarine by a dilution factor of 1:10. The accuracy and precision within- and between-run of dilution tests had to be within $\pm 15 \%$. The matrix effect was determined by using six QCA and QCC serum samples and one of each QCA and QCC sample prepared in ultra-purified water instead of serum. For each analyte and internal standard, the matrix factor (MF) was determined for each type of matrix, by calculating the ratio of the peak area in the presence of matrix to the peak area in the absence of matrix.

\section{Results and Discussion}

\section{Selectivity}

The andarine method: no significant interference at the retention time of andarine $(1.45 \mathrm{~min})$ and internal standard (1.61 min) was observed, the blank samples response being less than $20 \%$ compared to the response of the LLOQ of the analyte (andarine) and less than $5 \%$ for the internal standard (ostarine) (Figure 3).

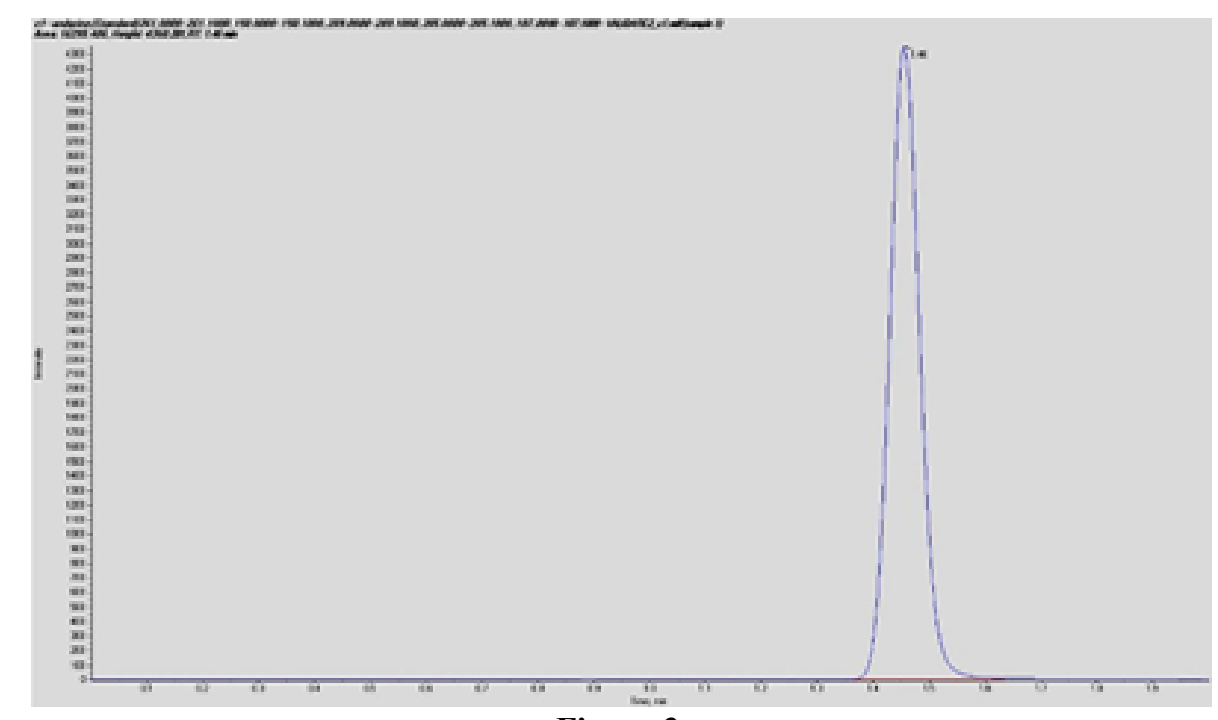

Figure 3.

Selectivity of the andarine method: the extracted chromatogram of the solution at LLOQ $(50 \mathrm{ng} / \mathrm{mL})$

The ostarine method: no significant interference at the retention time of ostarine $(1.64 \mathrm{~min})$ and internal standard (1.5 min) was observed, the blank samples response being less than $20 \%$ compared to the response of the LLOQ of the analyte (ostarine) and less than $5 \%$ for the internal standard (andarine) (Figure 4 ). 


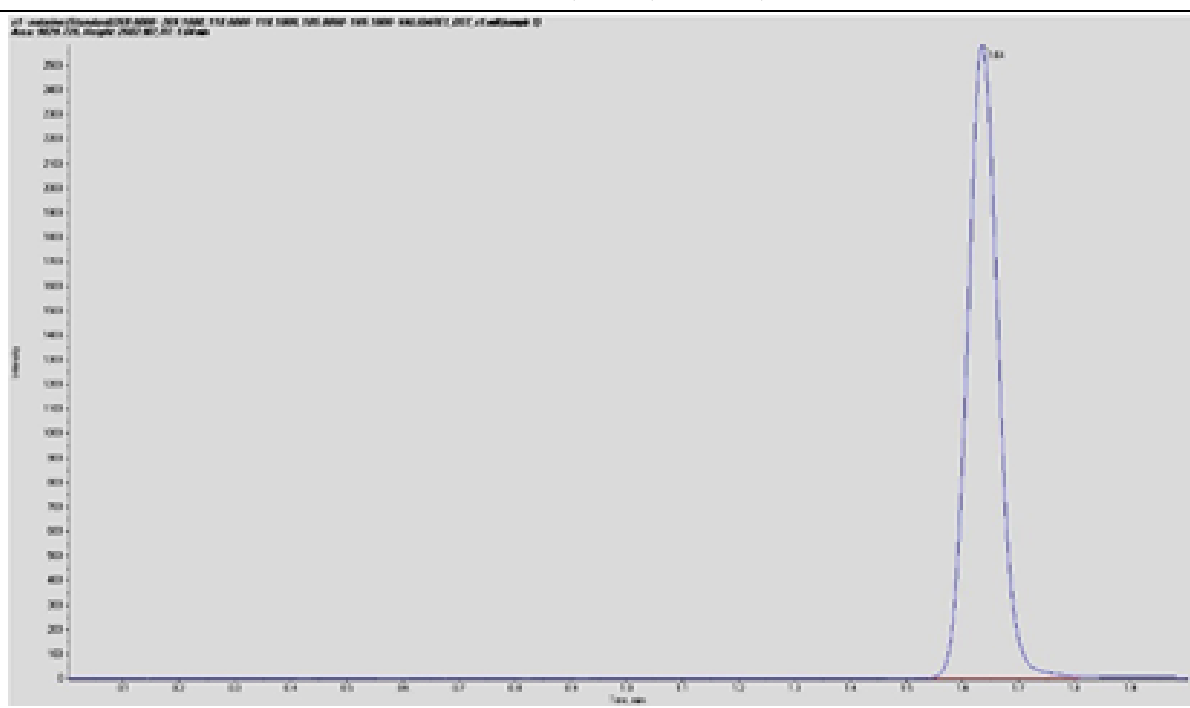

Figure 4.

Selectivity of the ostarine method: the extracted chromatogram of the solution at LLOQ $(50 \mathrm{ng} / \mathrm{mL})$

Regarding the carry-over of the two methods, the responses were less than $20 \%$ of the response of the LLOQ for the analytes and less than $5 \%$ for the internal standards. No significant carryover was observed. Linearity

The applied calibration curve model proved to be accurate over the concentration range $50-10000$ $\mathrm{ng} / \mathrm{mL}$ for andarine and ostarine, respectively. Each of the five calibration curves for each method was linear with correlation coefficients between 0.9954 and 0.9973 for andarine and between 0.9958 and 0.9984 for ostarine.

Accordingly to the current European guideline of bioanalytical method validation [1], the within- and between-run accuracy and precision of the methods were calculated and the results are presented in Tables I, II, III and IV.

Table I

Accuracy and precision within-run for andarine method

\begin{tabular}{|c|c|c|c|c|}
\hline Level & LLOQ & QCA & QCB & QCC \\
\hline Replicate & $\mathbf{5 0} \mathbf{~ n g / m L}$ & $\mathbf{1 5 0} \mathbf{~ n g} / \mathbf{m L}$ & $\mathbf{3 0 0 0} \mathbf{~ n g} / \mathbf{m L}$ & $\mathbf{7 5 0 0} \mathbf{~ n g} / \mathbf{m L}$ \\
\hline 1 & 50.90 & 147.88 & 3233.91 & 7015.38 \\
\hline 2 & 55.61 & 128.17 & 3083.40 & 7106.57 \\
\hline 3 & 57.12 & 132.32 & 2633.69 & 6562.65 \\
\hline 4 & 56.41 & 159.07 & 2888.41 & 7246.87 \\
\hline 5 & 53.27 & $122.82^{*}$ & 2767.17 & 6663.99 \\
\hline Mean & 54.66 & 147.88 & 2921.31 & 7015.38 \\
\hline SD & 2.55 & 15.00 & 240.60 & 293.25 \\
\hline Mean Accuracy (\%) & 109.30 & 92.00 & 97.40 & 92.30 \\
\hline \%RSD & 4.70 & 10.90 & 8.20 & 4.20 \\
\hline
\end{tabular}

*Outlier

Table II

Accuracy and precision between-run for andarine method

\begin{tabular}{|c|c|c|c|c|}
\hline Level & LLOQ & QCA & QCB & QCC \\
\hline Replicate & $\mathbf{5 0} \mathbf{~ n g / m L}$ & $\mathbf{1 5 0} \mathbf{~ n g} / \mathbf{m L}$ & $\mathbf{3 0 0 0} \mathbf{~ n g} / \mathbf{m L}$ & $\mathbf{7 5 0 0} \mathbf{~ n g} / \mathbf{m L}$ \\
\hline 1 & 50.90 & 147.88 & 3233.91 & 7015.38 \\
\hline 2 & 41.99 & 142.14 & 2625.72 & 6423.98 \\
\hline 3 & 53.57 & 135.30 & 2680.64 & 6379.56 \\
\hline 4 & 53.25 & 140.02 & 2967.73 & 6707.91 \\
\hline 5 & 46.02 & 170.22 & $2459.39^{*}$ & 6943.90 \\
\hline Mean & 49.14 & 147.11 & 2793.47 & 6694.14 \\
\hline SD & 5.01 & 13.68 & 306.93 & 290.56 \\
\hline Mean Accuracy (\%) & 98.30 & 98.10 & 93.10 & 89.30 \\
\hline \%RSD & 10.20 & 9.30 & 11.00 & 4.30 \\
\hline
\end{tabular}

*Outlier 
Table III

Accuracy and precision within-run for ostarine method

\begin{tabular}{|c|c|c|c|c|}
\hline Level & LLOQ & QCA & QCB & QCC \\
\hline Replicate & $50 \mathrm{ng} / \mathrm{mL}$ & $150 \mathrm{ng} / \mathrm{mL}$ & $4000 \mathrm{ng} / \mathrm{mL}$ & $7500 \mathrm{ng} / \mathrm{mL}$ \\
\hline 1 & 57.52 & 167.30 & 4080.89 & 8133.35 \\
\hline 2 & 55.56 & 149.30 & 3801.61 & 6635.89 \\
\hline 3 & 53.36 & 165.40 & $4895.12^{*}$ & 8410.90 \\
\hline 4 & 56.39 & 162.58 & 4541.06 & 7863.23 \\
\hline 5 & 50.52 & 160.52 & 4409.43 & 7312.11 \\
\hline Mean & 54.67 & 161.02 & 4345.62 & 7671.09 \\
\hline SD & 2.77 & 7.04 & 421.38 & 706.82 \\
\hline Mean Accuracy (\%) & 109.30 & 107.30 & 108.60 & 102.30 \\
\hline \%RSD & 5.10 & 4.40 & 9.70 & 9.20 \\
\hline
\end{tabular}

Table IV

Accuracy and precision between-run for ostarine method

\begin{tabular}{|c|c|c|c|c|}
\hline Level & LLOO & $\frac{\text { Accuracy at }}{\text { OCA }}$ & $\frac{\text { ecision betwe }}{\text { OCB }}$ & oCC \\
\hline Replicate & $50 \mathrm{ng} / \mathrm{mL}$ & $150 \mathrm{ng} / \mathrm{mL}$ & $4000 \mathrm{ng} / \mathrm{mL}$ & $7500 \mathrm{ng} / \mathrm{mL}$ \\
\hline 1 & 57.52 & 167.30 & 4080.89 & 8133.35 \\
\hline 2 & 54.89 & 168.02 & 4216.48 & 8514.92 \\
\hline 3 & 53.16 & 164.41 & 4140.85 & 8511.73 \\
\hline 4 & 55.53 & 152.88 & 3980.89 & 8332.06 \\
\hline 5 & $60.97 *$ & 147.78 & 3978.66 & 7743.52 \\
\hline Mean & 56.41 & 160.07 & 4080.89 & 8247.11 \\
\hline SD & 2.98 & 9.17 & 102.98 & 322.29 \\
\hline Mean Accuracy \% & 112.80 & 106.70 & 102.00 & 110.00 \\
\hline \%RSD & 5.30 & 5.70 & 2.50 & 3.90 \\
\hline
\end{tabular}

Table V

Results of the stability studies for andarine and ostarine

\begin{tabular}{|l|c|c|c|c|c|c|}
\hline \multirow{2}{*}{$\mathbf{C}_{\text {nominal }}(\mathbf{n g} / \mathbf{m L})$} & \multicolumn{2}{|c|}{ FTS } & \multicolumn{2}{c|}{ STS } & \multicolumn{2}{c|}{ PPS } \\
\cline { 2 - 7 } & $\mathbf{1 5 0}(\mathbf{Q C A})$ & $\mathbf{7 5 0 0}(\mathbf{Q C C})$ & $\mathbf{1 5 0}(\mathbf{Q C A})$ & $\mathbf{7 5 0 0}(\mathbf{Q C C})$ & $\mathbf{1 5 0}(\mathbf{Q C A})$ & $\mathbf{7 5 0 0}(\mathbf{Q C C})$ \\
\hline Mean accuracy for andarine (\%) & 91.70 & 86.40 & 95.60 & 98.2 & 96.6 & 90.6 \\
\hline Mean accuracy for ostarine (\%) & 108.70 & 97.30 & 109.40 & 108.50 & 106.40 & 104.90 \\
\hline
\end{tabular}

FTS, freeze - thaw stability; STS, short term room temperature stability; PPS, post-preparative stability

The analytes proved to be stable in various conditions (Table V) and the calculated mean accuracy (\%) was between $\pm 15 \%$.

With regards to the dilution integrity (dilution factor $=10$ ), the accuracy and precision within- and between-runs for the two validated methods are presented in Table VI.

Table VI

Within- and between-run accuracy and precision of dilution integrity for andarine and ostarine

\begin{tabular}{|l|c|c|}
\hline \multicolumn{1}{|c|}{$\mathbf{C}_{\text {nominal }}$ (ng/mL) } & $\mathbf{8 5 0 0}$ & $\mathbf{8 0 0 0}$ \\
\cline { 2 - 3 } & Andarine & Ostarine \\
\hline Mean accuracy within-run (\%) & 110.69 & 112.70 \\
\hline Mean precision within-run (\%) & 111.50 & 104.20 \\
\hline Mean accuracy between-run (\%) & 100.70 & 100.20 \\
\hline Mean precision between-run (\%) & 105.30 & 111.90 \\
\hline
\end{tabular}

The results for matrix effect testing are presented in Table VII, represented by the ratio of the analytes area in the presence of serum and the analytes area in water, normalized by the same ratio for the internal standard.
Table VII

Matrix effect study results

\begin{tabular}{|c|c|c|c|c|}
\hline \multirow{2}{*}{ QC nr. } & \multicolumn{4}{|c|}{ IS-Normalized MF } \\
\cline { 2 - 5 } & \multicolumn{2}{|c|}{ Andarine } & \multicolumn{2}{c|}{ Ostarine } \\
\cline { 2 - 5 } & QCA & QCC & QCA & QCC \\
\hline 1 & 0.96 & 1.08 & 1.22 & 0.93 \\
\hline 2 & 1.14 & 1.00 & 1.04 & 0.92 \\
\hline 3 & 0.98 & 0.94 & 1.00 & 0.87 \\
\hline 4 & 1.14 & 1.14 & 0.99 & 0.94 \\
\hline 5 & 1.06 & 0.93 & 1.08 & 1.02 \\
\hline 6 & 1.23 & 0.97 & 1.04 & 1.00 \\
\hline Mean & 1.08 & 1.01 & 1.06 & 0.95 \\
\hline \%RSD & 9.60 & 8.30 & 8.00 & 5.70 \\
\hline
\end{tabular}

The two methods were developed and validated in order to determine the SARMs serum concentrations in samples obtained from rats treated for doping purposes by oral gavage with single dose andarine $(5 \mathrm{mg} / \mathrm{kg}$ bw/day) and single dose ostarine $(3 \mathrm{mg} / \mathrm{kg}$ bw/day), respectively. The biological samples were collected after 30 minutes after administration the single dose of andarine and ostarine, respectively. 
The biological applicability of the methods was demonstrated as depicted in Table VIII which presents, in summary, the results of the analysis of rat serum samples obtained during these studies, after 20 days of andarine administration and 5 days of ostarine administration.

\section{Table VIII}

Results of rat serum samples treated with andarine and ostarine

\begin{tabular}{|l|c|}
\hline Rat serum samples & $\begin{array}{c}\text { Average } \pm \text { SD } \\
\text { (Min-Max; ng/mL) }\end{array}$ \\
\hline Andarine $(\mathrm{n}=20)$ & $1817.86 \pm 582.90$ \\
& $(1073.69-2760.18)$ \\
\hline Ostarine $(\mathrm{n}=20)$ & $2027.06 \pm 823.35$ \\
& $(901.06-3878.68)$ \\
\hline
\end{tabular}

The developed methods allow the determination of andarine and ostarine parent compounds in serum samples. This approach is justified taking into account that it is not always necessary to determine the specific metabolites; as for example, ostarine is present unmetabolized in urine up to 6 days after administration [7]. On the other hand, the study of the metabolites of these substances has certain drawbacks due to the complex metabolic biochemical pathways and the difficulties in procuring them as standards, therefore the need to synthesize them in-house [9].

Moreover, the methods developed have a major advantage due to not requiring any time consuming and costly sample preparation, but rather a simple protein precipitation technique, as all currently published methods for andarine and ostarine determinations in different biological matrices describe the use of liquidliquid extraction as method of processing the samples. Another advantage of our LC-MS/MS methods, which are almost identical, is the ability to determine both andarine and ostarine, using one as the internal standard for the other, and vice-versa, this being achieved in a very short run-time of only 2 minutes for each sample.

\section{Conclusions}

The LC-MS/MS methods developed and validated for the quantitative analysis of andarine and ostarine provide accuracy and precision for determination of the two SARMs in rat serum, with applicability in pharmacokinetic and doping research purposes. The methods provide rapid and simple analysis of the selected SARMs in serum samples using high-throughput sample preparation by protein precipitation, a short sample run time and, nevertheless, with a limit of quantification low enough to allow ostarine and andarine determination in animal doping models.

The proposed methods proved to be suitable for andarine and ostarine levels monitoring in rat serum for our experimental studies. In order to be applied to human serum samples, these methods need further optimization and moreover, for doping tests applied to different biological samples like urine or hair, the methods should be optimized and validated to obtain an appropriate lower LLOQ, below $50 \mathrm{ng} / \mathrm{mL}$.

\section{Acknowledgement}

The authors thank for the technical support of Chromatography and Mass Spectrometry Laboratory (CROMS) from Center for Advanced Medical and Pharmaceutical Research (CCAMF) of University of Medicine, Pharmacy, Sciences and Technology (UMFST) of Târgu Mureș, Romania.

\section{References}

1. $* * *$ www.ema.europa.eu/docs/enGB/documentlibra ry/Scientificguideline/2011/08/WC500109686.pdf

2. $* * *$ www.wada-ama.org/en/content/what-isprohibited/prohibited-at-all-times/anabolic-agents

3. Carrasquillo R, Chu K, Ramasamy R, Novel therapy for male hypogonadism. Curr Urol Rep., 2018; 19(8): 63.

4. Cesbron N, Sydor A, Penot M, Prevost S, Le Bizec B, Dervilly-Pinel G, Analytical strategies to detect enobosarm administration in bovines. Food Addit Contam Part A Chem Anal Control Expo Risk Assess., 2017; 34(4): 632-640.

5. Clark RV, Walker AC, Andrews S, Turnbull P, Wald JA, Magee MH, Safety, pharmacokinetics and pharmacological effects of the selective androgen receptor modulator, GSK2881078, in healthy men and postmenopausal women. Br J Clin Pharmacol., 2017; 83(10): 2179-2194.

6. Dalton JT, The long and winding road for selective androgen receptor modulators, Br J Clin Pharmacol., 2017; 83: 2131-2133.

7. de Rijkea E, Essersa ML, Rijka JCW, Thevis M, Boveea TFH, van Ginkela LA, Sterk SS, Selective androgen receptor modulators: in vitro and in vivo metabolism and analysis. Food Additives \& Contaminants: Part A, 2013; 30(1): 1517-1526.

8. Fujii S, Kagechika H, Androgen receptor modulators: a review of recent patents and reports (2012-2018). Exp Opin Ther Pat., 2019; 29(6): 439-453.

9. Garg N, Hansson A, Knych HK, Stanley SD, Thevis M, Bondesson U, Hedeland M, Globisch D, Structural elucidation of major selective androgen receptor modulator (SARM) metabolites for doping control. Org Biomol Chem., 2018; 16: 698-702.

10. Hoffmann DB, Komrakova M, Pflug S, von Oertzen M, Saul D, Weiser L, Walde TA, Wassmann M, Schilling AF, Lehmann W, Sehmisch S, Evaluation of ostarine as a selective androgen receptor modulator in a rat model of postmenopausal osteoporosis. J Bone Mineral Metab., 2019; 37(2): 243-255.

11. Kintz P, Ameline A, Gheddar L, Raul JB, LGD-4033, S-4 and MK-2866 - Testing for SARMs in hair: About 2 doping cases. Toxicol Anal Clin., 2019; 31: 56-63.

12. Miklos A, Tero-Vescan A, Vari CE, Ösz BE, Filip C, Rusz CM, Muntean DL, Selective androgen receptor modulators (SARMs) in the context of doping. Farmacia, 2018; 66(5): 758-762.

13. Molfino A, Amabile MI, Rossi Fanelli F, Muscaritoli M, Novel therapeutic options for cachexia and sarcopenia. Exp Opin Biol Ther., 2016; 16(10): 1239-1244. 
14. Muta Y, Tanaka T, Hamaguchi Y, Hamanoue N, Motonaga R, Tanabe M, Nomiyama T, Nawata H, Yanase T, Selective androgen receptor modulator, S42 has anabolic and anti-catabolic effects on cultured myotubes. Biochem Biophys Rep., 2019; 17: 177-181.

15. Neil D, Clark RV, Magee M, Billiard J, Chan A, Xue Z, Russell A, GSK2881078, a SARM, Produces Dose-Dependent Increases in Lean Mass in Healthy Older Men and Women. J Clin Endocrinol Metab., 2018; 103(9): 3215-3224

16. Piţigoi G, Păunescu C, Mitrea N, Baconi D, Păunescu $\mathrm{M}$, Burcea C, Arsene AL, New approaches regarding the dynamics of the doping pharmacologic agents in sports. Farmacia, 2012; 60(1): 111-119.

17. Vari CE, Ösz BE, Perian M, Mărușteri MȘ, Miklos A, Bosa P, Tero-Vescan A, Do aromatase inhibitors reduce fertility and impair sexual behaviour in an androgen doping model in rats?. Farmacia, 2017; 65(3): 336-342.
18. Vari CE, Ösz BE, Miklos A, Berbecaru-Iovan A, Tero-Vescan A, Aromatase inhibitors in men - offlabel use, misuse, abuse and doping. Farmacia, 2016; 64(6): 813-818.

19. Ventura E, Gadaj A, Monteith G, Ripoche A, Healy $\mathrm{J}$, Botrè F, Sterk SS, Buckley T, Mooney MH, Development and validation of a semi-quantitative ultra-high performance liquid chromatography-tandem mass spectrometry method for screening of selective androgen receptor modulators in urine. J Chromatogr A., 2019; 1600: 183-196.

20. Yatsu T, Kusakabe T, Kato K, Inouye Y, Nemoto K, Kanno Y, Selective Androgen Receptor Modulator, YK11, Up-Regulates Osteoblastic Proliferation and Differentiation in MC3T3-E1 Cells. Biol Pharm Bull., 2018; 41(3): 394-398.

21. Zhang $X$, Sui Z, Deciphering the selective androgen receptor modulators paradigm. Exp Opin Drug Discov., 2013; 8(2): 191-218. 